\title{
Free amino acids extracted from dried Gugija (Lycium chinensis) under different extraction conditions
}

\author{
Gee-Dong Lee \\ Division of Integrated Biotechnology, Joongbu University, Geumsan 32713, Korea
}

\section{건조 구기자의 추출조건에 따른 유리아미노산의 변화}

\author{
이기동 \\ 중부대학교 바이오융합학부
}

\begin{abstract}
The amounts of free amino acids extracted from dried Gugija (Lycium chinensis Mill) were monitored under different extraction conditions. The response methodology was applied using the ethanol concentration $\left(\mathrm{X}_{1} \mathbf{0 - 8 0} \%\right)$ and extraction time $\left(X_{2} 1-5 \mathrm{~h}\right)$ as operational parameters with regard to various free amino acids (glycine, serine, alanine, threonine, proline, valine, methionine, isoleucine, leucine, tyrosine, tryptophan, phenylalanine, asparagine, lysine, arginine, histidine, camosine, omithine, aspartic acid, glutamic acid, phosphoserine, hydroxyproline, $\gamma$-amino-n-butyric acid, taurine, phosphoethanolamine, citrulline, $\beta$-alanine, $\beta$-amino-isobutyric acid, hydroxylysine, sarcocine, and ethanolamine) and their sum. Under the optimum conditions, the free amino acid contents were asparagine 186.28, phosphoethanolamine 166.21, proline 46.51, alanine 43.35, aspartic acid 27.23 , hydroxyproline 21.17 , glutamic acid 16.53, taurine 16.24, arginine 14.66, serine 11.65, $\gamma$-amino-n-butyric acid 10.82, leucine 10.52, tryptophan 8.75 , ethanolamine 8.49, and total free amino acid $629 \mathrm{mg} / 100 \mathrm{~g}$. The coefficients of determination $\left(R^{2}\right)$ of the models for methionine, arginine, histidine, carnosine, omithine, aspartic acid, phosphoserine and $\mathrm{y}$-amino-n-butyric acid were within 0.9052-0.9810 (p<0.01-0.05). For the total free amino acids, the $R^{2}$ of the model was $0.8608(p<0.1)$, the extraction yield ranged from 282 to $641 \mathrm{mg} / 100 \mathrm{~g}$ depending on the extraction conditions and was the highest when extracted for $5 \mathrm{~h}$ with $20 \%$ ethanol.
\end{abstract}

Key words : Gugija (Lycium chinensis Mill), extraction condition, free amino acid, response surface methodology, monitoring

\section{서 론}

최근 구기자의 효능이 널리 알려지면서 구기자 가공제품 이 다양하게 시판되고 있다. 구기자를 가공하는 대표적인 방법은 구기자 유용성분을 물로 추출하여 음료나 차로 마시 는 것이다. 그러나 아직 구기자의 추출방법에 대한 구체적 인 연구가 많이 이루어지지 않아 전통적인 열탕추출법에

*Corresponding author. E-mail : geedlee@jbm.ac.kr Phone : 82-41-750-6291, Fax : 82-41-750-6160

Received 8 March 2018; Revised 5 April 2018; Accepted 9 April 2018.

Copyright (c) The Korean Society of Food Preservation. All rights reserved.
크게 의존하고 있다.

청양 구기자의 유리아미노산은 18 종이 보고되었고 serine이 가장 많았으나, methionine과 asparagine은 들어 있 지 않았다(1). 청양 구기자의 채취시기와 품종에 따른 구기 자순의 구성 아미노산이 19종류가 확인되었으며, aspartic acid, glutamic acid, glycine, alanine 등의 함량이 상대적으로 많은 것으로 보고되었다(2).

청양산 볶은 구기자를 이용한 구기자추출물 $70 \%$ 에 오미 자추출물 $10 \%$ 를 첨가한 구기자음료의 아미노산은 16 종류 의 유리형의 구성 아미노산과 6 종류의 유리형 비구성 아미 노산이 보고되었으며, 구성 아미노산에서는 methionine이 가장 많았으며, 비구성 아미노산에서는 taurine 및 asparagine 이 가장 많은 것으로 알려졌다(3). 
진도산 구기자의 구성 아미노산은 aspartic acid 등 18 종 이 보고되었으며 threonine이 특별히 많았다. 당류는 과당이 가장 많았으며 포도당, 설탕 순으로 많은 것으로 보고되었 다(4). 그러나 진도산 구기자에 대한 다른 연구는 aspartic acid와 asparagine이 가장 많다고 보고하였으며 methionine 은 상대적으로 적은 함량이 확인되었다(5). 이것은 실험에 사용된 구기자 시료의 채취부위, 종류, 부위, 단백질의 가수 분해 유무 및 가공에 따라 많은 차이를 보이고 있는 것이다 $(6,7)$.

이와 같이 아미노산이 풍부한 구기자는 오래전부터 장수 식품으로 알려져 구기자 열매를 열탕에 끓여 그 추출물을 건강 기호식품인 차로 즐겨 먹어 왔다. 청양 구기자의 항산 화성에 대한 다양한 연구가 이루어져 왔으며, 건조 구기자 의 항산화성분에는 페놀성 화합물, 플라보노이드 및 안토 시아닌 성분이 확인되었으며 플라보노이드와 같은 페놀성 화합물이 항산화 효과에 주로 관여하고 있는 것으로 밝혀졌 다 $(8,9)$. 또한 구기자를 $100^{\circ} \mathrm{C}$ 에서 30 분간 증자 후 상온에서 2 시간 동안 말리는 과정을 4 회 반복한 증포 구기자는 갈변 물질이 아주 많이 발현되었으며, 이러한 갈변물질이 구기 자 플라보노이드 보다 항산화 효능이 훨씬 더 많아 건조 구기자의 8 배까지 증가한다는 것이 최근 보고되었다(10). 우리 선조들이 열탕으로 끓여 마시는 구기자차에는 항산화 효능이 우수한 갈변물질이 다량 함유되어 있어 구기자가 장수식품으로 지금껏 이어져 내려온 것으로 보인다.

따라서 본 연구에서는 청양군에서 가장 많이 생산 및 판매되는 건조 구기자의 추출 중 각종 유리아미노산의 변화 를 모니터링 함으로써 아미노산 함량변화를 조사하고 그 아미노산이 갈변물질로 전환되거나 소실되는 동적변화를 알아보고자 하였다.

\section{재료 및 방법}

\section{실험재료}

본 실험에 사용된 구기자(Lycium chinensis Mill)는 충남 청양군 청양구기자농협에서 건조구기자를 구입하여 시료 로 사용하였다. 구기자의 전처리는 건조 구기자를 분쇄기 (Samsung Pharmaceutical Machine, Seoul, Korea)로 마쇄하 여 20-40 메쉬 분말을 추출시료로 사용하였다.

\section{실험계획 및 반응표면분석}

추출조건은 환류냉각기에 부착한 $250 \mathrm{~mL}$ 둥근플라스크 에 구기자 분말 $20 \mathrm{~g}$ 과 추출용매 $200 \mathrm{~mL}$ 를 넣고 $70^{\circ} \mathrm{C}$ 에서 일정 시간 추출하였다. 이 때 추출용매의 에탄올 농도와 추출 시간은 실험계획에 따라 설정하였다.

건조 구기자의 추출조건에 따른 각각의 유리아미노산 및 그 유도체의 변화를 모니터링하기 위한 실험계획은 중심
합성계획법(11)에 의하여 설계하였고, 중심합성 실험계획 에 따라 추출용매로서 에탄올의 농도 $(0,20,40,60,80 \%)$ 및 추출 시간 $(1,2,3,4,5 \mathrm{~h})$ 은 $-2,-1,0,1,2$ 다섯 단계로 부호화 하였으며, 실험계획은 Table 1에 나타내었다. 종속 변수로는 31종류의 유리 아미노산과 그 유도체로 하였으 며, 반응표면분석을 위한 각각의 유리아미노산 함량은 3회 반복 분석한 수치를 평균하여 사용하였다. 반응표면 회귀 분석을 위해서는 SAS program(Statistical Analysis System, ver. 8.01, SAS Institute Inc., Cary, NC, USA)을 사용하였다.

Table 1. Central composite design for response surface analysis

\begin{tabular}{ccc}
\hline \multirow{2}{*}{$\left.\operatorname{Exp}_{i}\right)$} & \multicolumn{2}{c}{ Extraction conditions } \\
\cline { 2 - 3 } No. & Ethanol concentration (\%) & Extraction time (h) \\
\hline 1 & $60(1)$ & $4(1)$ \\
2 & $60(1)$ & $2(-1)$ \\
3 & $20(-1)$ & $4(1)$ \\
4 & $20(1)$ & $2(-1)$ \\
5 & $40(0)$ & $3(0)$ \\
6 & $40(0)$ & $3(0)$ \\
7 & $80(2)$ & $3(0)$ \\
8 & $0(-2)$ & $3(0)$ \\
9 & $40(0)$ & $5(2)$ \\
10 & $40(0)$ & $1(-2)$ \\
\hline
\end{tabular}

${ }^{1)}$ The number of experimental conditions by central composite design.

유리 아미노산 함량 측정

구기자추출물의 아미노산분석을 위한 시료는 구기자분 말을 중심합성 실험계획에 따라 물 또는 에탄올용액으로 추출하여 상등액을 취하였다. 상등액은 $0.2 \mu \mathrm{m}$ membrane filter(Millipore Co., MA, USA)로 여과한 후 아미노산 자동 분석기(Sykam GmbH, S430-H, Germany)를 사용하여 Table 2 와 같은 조건으로 유리 아미노산 함량을 측정하였다. Column은 cation separation column(LCA K07/Li)을 사용하 였으며, 크기는 $4.6 \times 150 \mathrm{~mm}$ 이었고, 온도는 $37-74^{\circ} \mathrm{C}$ 이었고, 완충용액과 o-phthalal aldehyde(OPA)시약의 flow rate는 각 각 $0.45 \mathrm{~mL} / \mathrm{min}, 0.25 \mathrm{~mL} / \mathrm{min}$ 이었으며, 이때 완충용액의

Table 2. Operating conditions of amino acid auto-analyzer

\begin{tabular}{cl}
\hline Instrument & S430 (SYKAM) \\
Column & Cation separation column (LCA K07/Li) \\
Column size & $4.6 \times 150 \mathrm{~mm}$ \\
Column temperature & $37-74^{\circ} \mathrm{C}$ \\
Flow rate & Buffer $0.45 \mathrm{~mL} / \mathrm{min}$, reagent $0.25 \mathrm{~mL} / \mathrm{min}$ \\
Buffer pH range & $2.90-7.95$ \\
Wave length & $440 \mathrm{~nm}$ and $570 \mathrm{~nm}$ \\
\hline
\end{tabular}


$\mathrm{pH}$ 범위는 2.90-7.95이었고, 파장은 $440 \mathrm{~nm}$ 및 $570 \mathrm{~nm}$ 을 적용하였다.

\section{결과 및 고찰}

중성 유리아미노산의 변화

건조 구기자의 추출에 따른 중성 유리아미노산의 변화를
관찰해 본 결과, 에탄올 농도 및 추출 시간의 변화에 따른 유리아미노산의 변화가 다소 있는 것으로 나타났다(Table 3). Glycine은 0.78-1.32 mg/100 g로 에탄올의 농도와 추출 시간에 따라 변화가 많았으나 상대적으로 그 함량이 높지 않았으며, serine은 4.06-12.37 mg/100 g로 큰 변화가 있었으 며, alanine과 proline은 28.86-44.71과 36.72-54.28 mg/100 $\mathrm{g}$ 으로 변화의 폭은 크지 않았으나 그 함량이 높게 나타났다.

Table 3. Experimental data on free amino acids of the dried Gugija (Lycium chinensis Mill) under different conditions based on central composite design for response surface analysis

(unit: $\mathrm{mg} / 100 \mathrm{~g}$ )

\begin{tabular}{|c|c|c|c|c|c|c|c|c|c|c|}
\hline \multirow{2}{*}{ Amino acids } & \multicolumn{10}{|c|}{ The number of experimental conditions by central composite design } \\
\hline & 1 & 2 & 3 & 4 & 5 & 6 & 7 & 8 & 9 & 10 \\
\hline Glycine & $0.952^{1)}$ & 0.782 & 1.138 & 1.038 & 1.176 & 1.266 & 0.525 & 1.183 & 1.322 & 1.166 \\
\hline Serine & 7.687 & 7.472 & 9.544 & 9.335 & 12.367 & 10.894 & 4.055 & 9.628 & 9.868 & 10.689 \\
\hline Alanine & 35.226 & 33.485 & 42.379 & 37.864 & 44.006 & 42.788 & 28.859 & 41.440 & 44.705 & 42.139 \\
\hline Threonine & 3.838 & 3.017 & 4.548 & 3.647 & 6.044 & 5.544 & 2.805 & 3.956 & 5.161 & 4.595 \\
\hline Proline & 37.999 & 37.283 & 45.311 & 40.548 & 47.235 & 46.856 & 36.722 & 45.045 & 54.286 & 47.508 \\
\hline Valine & 3.502 & 3.159 & 4.279 & 3.530 & 4.273 & 4.112 & 3.046 & 4.420 & 4.512 & 4.018 \\
\hline Methionine & 1.128 & 1.019 & 1.942 & 1.957 & 1.485 & 1.408 & 1.081 & 2.180 & 1.139 & 1.103 \\
\hline Isoleucine & 3.796 & 3.758 & 4.527 & 4.158 & 4.872 & 4.980 & 2.890 & 4.942 & 5.106 & 4.976 \\
\hline Leucine & 7.968 & 7.386 & 9.332 & 8.450 & 10.756 & 10.361 & 4.689 & 11.351 & 11.639 & 9.342 \\
\hline Tyrosine & 2.670 & 2.570 & 2.546 & 2.499 & 3.411 & 3.320 & 2.245 & 3.443 & 3.670 & 3.206 \\
\hline Tryptophan & 5.466 & 6.331 & 7.217 & 6.522 & 8.206 & 9.147 & 4.659 & 7.964 & 8.637 & 8.495 \\
\hline Phenylalanine & 2.876 & 2.644 & 3.316 & 2.613 & 3.325 & 3.371 & 2.884 & 3.752 & 3.447 & 3.126 \\
\hline Asparagine & 137.434 & 129.485 & 180.657 & 154.911 & 184.309 & 188.246 & 72.773 & 188.601 & 198.823 & 179.654 \\
\hline Lysine & 0.000 & 0.000 & 0.000 & 0.000 & 0.000 & 3.344 & 0.417 & 1.968 & 1.831 & 1.754 \\
\hline Arginine & 10.675 & 10.238 & 14.445 & 12.436 & 14.749 & 14.570 & 3.538 & 15.371 & 15.647 & 14.718 \\
\hline Histidine & 2.439 & 2.195 & 3.920 & 2.948 & 3.548 & 3.535 & 0.762 & 3.993 & 3.955 & 3.088 \\
\hline Carnosine & 0.423 & 0.577 & 0.875 & 0.831 & 0.868 & 0.815 & 0.150 & 0.788 & 0.744 & 0.969 \\
\hline Ornithine & 0.322 & 0.325 & 0.467 & 0.474 & 0.425 & 0.474 & 0.080 & 0.408 & 0.458 & 0.342 \\
\hline Aspartic acid & 17.326 & 17.967 & 25.680 & 21.396 & 28.121 & 27.433 & 5.427 & 24.590 & 27.509 & 26.153 \\
\hline Glutamic acid & 11.049 & 10.080 & 14.239 & 13.335 & 18.010 & 15.455 & 6.031 & 14.158 & 15.634 & 16.206 \\
\hline Phospho-serine & 2.915 & 3.293 & 3.071 & 3.382 & 4.037 & 3.600 & 1.240 & 2.721 & 3.070 & 4.016 \\
\hline Hydroxy-proline & 18.386 & 19.348 & 21.495 & 17.157 & 21.282 & 21.039 & 27.225 & 22.365 & 18.161 & 16.505 \\
\hline y-Amino-n-butyric acid & 7.974 & 7.974 & 10.292 & 9.311 & 10.870 & 10.765 & 4.654 & 9.013 & 9.047 & 8.580 \\
\hline Taurine & 11.890 & 12.211 & 7.106 & 5.649 & 16.365 & 16.197 & 4.293 & 16.140 & 16.335 & 17.077 \\
\hline Phospho-ethanolamine & 116.327 & 123.172 & 143.651 & 139.262 & 167.690 & 165.423 & 59.577 & 152.121 & 160.083 & 174.814 \\
\hline Citrulline & 1.211 & 1.173 & 1.360 & 1.078 & 1.443 & 1.074 & 1.074 & 1.335 & 1.449 & 1.355 \\
\hline$\beta$-Alanine & 0.019 & 0.000 & 0.031 & 0.000 & 0.031 & 0.000 & 0.000 & 0.000 & 0.030 & 0.000 \\
\hline B-Amino-isobutyric acid & 0.068 & 0.000 & 0.000 & 0.000 & 0.000 & 0.000 & 0.000 & 0.000 & 0.000 & 0.000 \\
\hline Hydroxy-lysine & 0.000 & 0.000 & 0.117 & 0.100 & 0.000 & 0.100 & 0.050 & 0.118 & 0.102 & 0.135 \\
\hline Sarcocine & 0.887 & 0.858 & 1.078 & 1.249 & 5.646 & 1.082 & 0.653 & 1.136 & 0.903 & 0.999 \\
\hline Ethanolamine & 13.312 & 12.860 & 16.500 & 14.060 & 16.492 & 0.440 & 0.038 & 0.092 & 0.088 & 0.045 \\
\hline Total amino acids & 465.762 & 460.662 & 581.061 & 519.740 & 641.041 & 617.641 & 282.439 & 594.221 & 627.358 & 606.770 \\
\hline
\end{tabular}

${ }^{1)}$ Data were expressed as mean of triplicate determinations. 
Threonine, valine, methionine, isoleucine, leucine, tyrosine, tryptophan, phenylalanine 등도 에탄올의 농도와 추출시간 에 따라 함량의 변화가 많았으며, 특히 asparagine은 $72.77-198.82 \mathrm{mg} / 100 \mathrm{~g}$ 으로 큰 차이를 보이고 그 함량도 유리아미노산 중에서 가장 많은 것으로 나타났다. Oh 등(1) 은 청양산 구기자의 구성 아미노산을 분석하여 serine이 가장 많이 분석되었다고 보고하였으나, 본 연구에서는 상 대적으로 serine 함량이 적었고 alanine, proline, asparagine 등이 많았다. 이렇게 차이가 나는 것은 단백질을 가수분해 한 구성 아미노산과 에탄올용액으로 추출한 유리아미노산 의 차이로 여겨진다.
중성 유리아미노산에 대한 회귀분석 결과(Table 4,5), methionine만이 $\mathrm{R}^{2}$ 가 0.9418로 유의수준 $5 \%$ 이내에서 유의 성이 인정되었으며, asparagine, glycine 및 serine은 $\mathrm{R}^{2}$ 가 $0.8843,0.8672$ 및 0.8390 으로 유의수준 $10 \%$ 이내에서 유의 성이 인정되었다. 그러나 나머지 중성 유리아미노산은 유 의성이 인정되지 않았으나 tyrosine을 제외하고는 $\mathrm{R}^{2}$ 가 높 은 편이었다. 추출변수인 에탄올 함량과 추출 시간이 중성 유리아미노산에 미치는 영향을 알아보고자 회귀분석을 통 해 F값을 구해 본 결과(Table 5), glycine, serine, alanine, methionine, asparagine 등 중성 아미노산이 에탄올 함량의 영향이 높게 나타났으나 추출 시간의 영향은 미미하였다.

Table 4. Polynomial equations calculated by RSM program for free amino acids of the dried Gugija

\begin{tabular}{|c|c|c|c|c|c|c|}
\hline \multirow{2}{*}{ Responses } & \multicolumn{6}{|c|}{ Parameters of polynomial equations ${ }^{1)}$} \\
\hline & $\beta_{0}$ & $\beta_{1}$ & $\beta_{2}$ & $\beta_{11}$ & $\beta_{12}$ & $\beta_{22}$ \\
\hline Glycine & 1.214500 & 0.006150 & -0.088500 & -0.000201 & 0.000875 & 0.017000 \\
\hline Serine & 7.157006 & 0.154630 & 1.243893 & -0.002710 & 0.000075 & -0.224732 \\
\hline Alanine & 35.778729 & 0.304895 & 0.540125 & -0.004422 & -0.034675 & 0.299313 \\
\hline Threonine & 1.521259 & 0.091370 & 1.137923 & -0.001294 & -0.00100 & -0.143348 \\
\hline Proline & 45.465372 & 0.258110 & -4.817196 & -0.002747 & -0.050587 & 1.404491 \\
\hline Valine & 3.587262 & 0.015135 & 0.062619 & -0.000202 & -0.005075 & 0.052286 \\
\hline Methionine & 1.665110 & -0.028874 & 0.483101 & 0.000097 & 0.001550 & -0.088545 \\
\hline Isoleucine & 4.613464 & 0.031921 & -0.226774 & -0.000517 & -0.004137 & 0.074643 \\
\hline Leucine & 9.017432 & 0.049358 & 0.061315 & -0.001297 & -0.003750 & 0.098920 \\
\hline Tyrosine & 3.428280 & 0.005174 & -0.337952 & -0.000204 & 0.000663 & 0.066839 \\
\hline Tryptophan & 5.717432 & 0.117208 & 0.237982 & -0.001179 & -0.019500 & 0.091920 \\
\hline Phenylalanine & 2.601688 & 0.003612 & 0.260792 & 0.000064 & -0.005887 & 0.017688 \\
\hline Asparagine & 150.731467 & 1.874236 & 0.817589 & -0.030726 & -0.222463 & 2.347277 \\
\hline Arginine & 12.686429 & 0.173718 & -0.300048 & -0.002978 & -0.019650 & 0.240786 \\
\hline Histidine & 2.084476 & 0.043981 & 0.481262 & -0.000661 & -0.009100 & 0.021429 \\
\hline Carnosine & 0.703092 & 0.016711 & -0.002577 & -0.000219 & -0.002475 & 0.009152 \\
\hline Ornithine & 0.233423 & 0.006338 & 0.099393 & -0.000131 & 0.0000500 & -0.013982 \\
\hline Aspartic acid & 13.596723 & 0.560666 & 2.801315 & -0.007310 & -0.061562 & 0.031795 \\
\hline Glutamic acid & 12.926979 & 0.196396 & 0.092375 & -0.003668 & 0.000813 & -0.010687 \\
\hline Phospho-serine & 2.484473 & 0.079266 & 0.178149 & -0.001126 & -0.000838 & -0.059955 \\
\hline Hydroxy-proline & 5.814036 & 0.024904 & 8.084690 & 0.002632 & -0.06625 & -0.812893 \\
\hline$\gamma$-Amino-n-butyric acid & 2.5708881 & 0.178305 & 3.489726 & -0.002413 & -0.012262 & -0.474107 \\
\hline Taurine & 12.667009 & 0.237720 & -2.199411 & -0.002781 & -0.022225 & 0.509902 \\
\hline Phospho-ethanolamine & 144.568033 & 2.204564 & -7.380673 & -0.034192 & -0.140425 & 1.722973 \\
\hline Citrulline & 1.157295 & 0.008373 & -0.083220 & -0.000020 & -0.003050 & 0.041259 \\
\hline Hydroxy-lysine & 0.291342 & -0.002839 & -0.107494 & 0.000025 & -0.000213 & 0.018652 \\
\hline Sarcocine & -3.491330 & 0.093448 & 3.009363 & -0.001342 & 0.002500 & -0.522866 \\
\hline Ethanolamine & -25.352872 & 0.617540 & 18.091613 & -0.007022 & -0.024850 & -2.808242 \\
\hline Total amino acids & 458.077863 & 7.309615 & 24.758381 & -0.106576 & -0.702763 & 2.053089 \\
\hline
\end{tabular}

${ }^{1)} Y$ (responses) $=\beta_{0}+\beta_{1} X_{1}+\beta_{2} X_{2}+\beta_{12} X_{1} X_{2}+\beta_{11} X_{1}^{2}+\beta_{22} X_{2}^{2}$. 
유의성이 인정되는 glycine, serine, methionine 및 asparagine 의 반응표면만을 관찰해 보면(Fig. 1), glycine은 에탄올 함 량 $30 \%$ 까지는 에탄올 함량 증가에 따른 변화가 없었으나 $30 \%$ 이상의 에탄올 함량에서는 급격히 감소하는 경향을 보이고 있다. 상대적으로 추출 시간의 영향은 크지 않았으 나 4시간까지는 다소 줄어드는 것처럼 보였으나 4시간 이 상에서는 glycine 함량이 다소 증가하는 것을 볼 수 있었다. Serine은 에탄올 $30 \%$ 까지는 에탄올 함량이 증가할수록 증 가하다가 $30 \%$ 이상에서는 급격히 감소하는 반응표면을 보였다. 그러나 glycine과는 반대로 3시간까지는 추출 시간 이 증가할수록 증가하다가 그 이상에서는 다소 감소하는 경향을 나타내었다. 이것은 고온 장시간 추출시 serine이 갈색화 반응에 관여하는 것으로 여겨진다. Methionine은 특이적으로 에탄올 함량과 반비례적으로 감소하는 경향을 나타내어 추출 수율이 에탄올 함량에 크게 영향을 받고 있는 것을 볼 수 있었다. Asparagine은 glycine과 유사한 경향을 나타내었으나 추출 시간이 증가할수록 완만하게 증가하는 경향을 나타내었다. 이러한 경향은 수용액이든 에탄올용액이든 관계없이 asparagine이 천천히 추출된다는 것을 보여주고 있다.
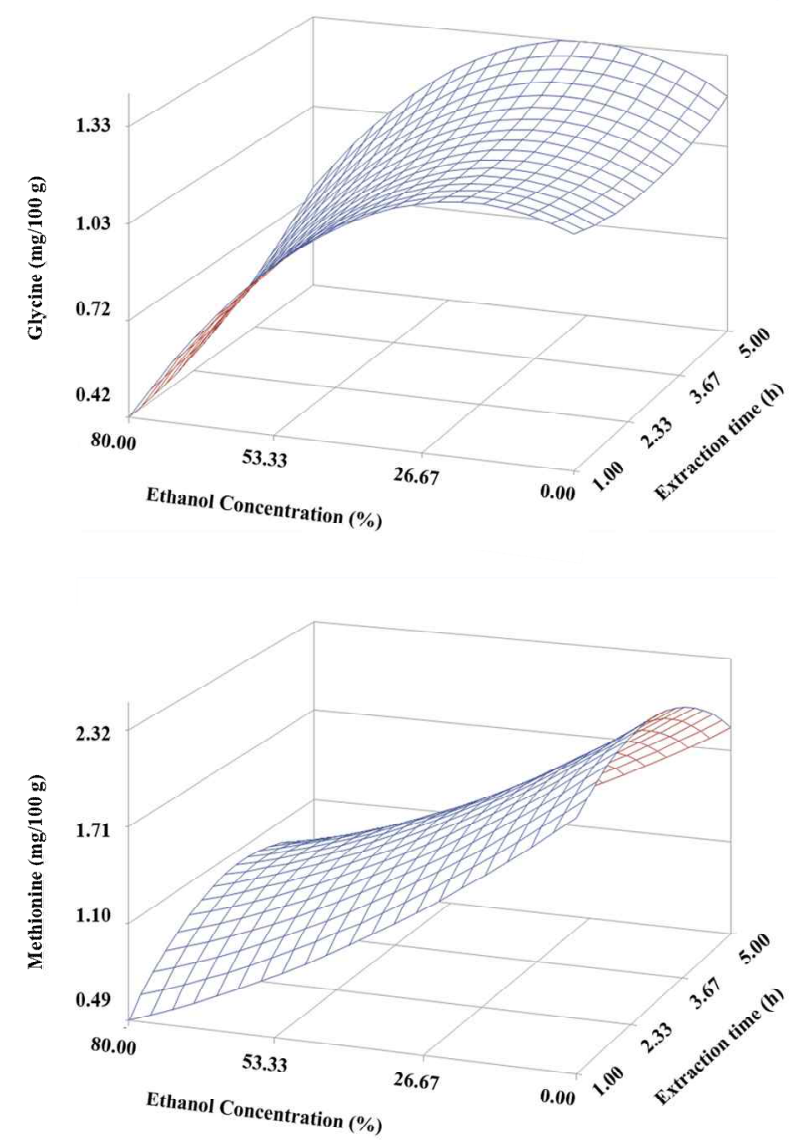

\section{염기성 유리아미노산의 변화}

건조 구기자의 추출에 따른 염기성 유리아미노산의 변화 를 관찰해 본 결과(Table 3), 에탄올 농도 및 추출 시간에 따라 lysine은 0.00-3.34 mg/100 g로 함량 변화가 아주 크게 나타났으며, lysine이 검출되지 않는 시료도 많았다. Arginine은 3.54-15.65 mg/100 g로 큰 변화가 있었으며, histidine은 0.762-3.99 mg/100 g로 변화의 폭은 크게 나타났 으며, 염기성 유리아미노산이 상대적으로 에탄올과 고온추 출에 변화가 큰 것으로 나타났다. 단백질을 구성하지 않은 아미노산 중 염기성을 띠고 있는 ornithine과 carnosine은 각각 $0.08-0.47 \mathrm{mg} / 100 \mathrm{~g}, 0.15-0.97 \mathrm{mg} / 100 \mathrm{~g}$ 로 변화가 큰 편이었으나 그 함량은 많지 않았다.

염기성 유리아미노산에 대한 회귀분석 결과(Table 4,5), lysine은 유의성이 인정되지 않으나 arginine과 histidine은 $\mathrm{R}^{2}$ 가 각각 $0.9074,0.9465$ 로 유의수준 $5 \%$ 이내에서 유의성 이 인정되었다. Ornithine과 carnosine은 $\mathrm{R}^{2}$ 가 각각 0.9685 , 0.9691 로 유의수준 $1 \%$ 이내에서 유의성이 인정되었다. 추 출변수인 에탄올 함량과 추출 시간이 염기성 유리아미노산 에 미치는 영향을 알아보고자 회귀분석을 통해 $\mathrm{F}$ 값을 구해 본 결과(Table 5), 대부분의 염기성 아미노산이 에탄올 함량
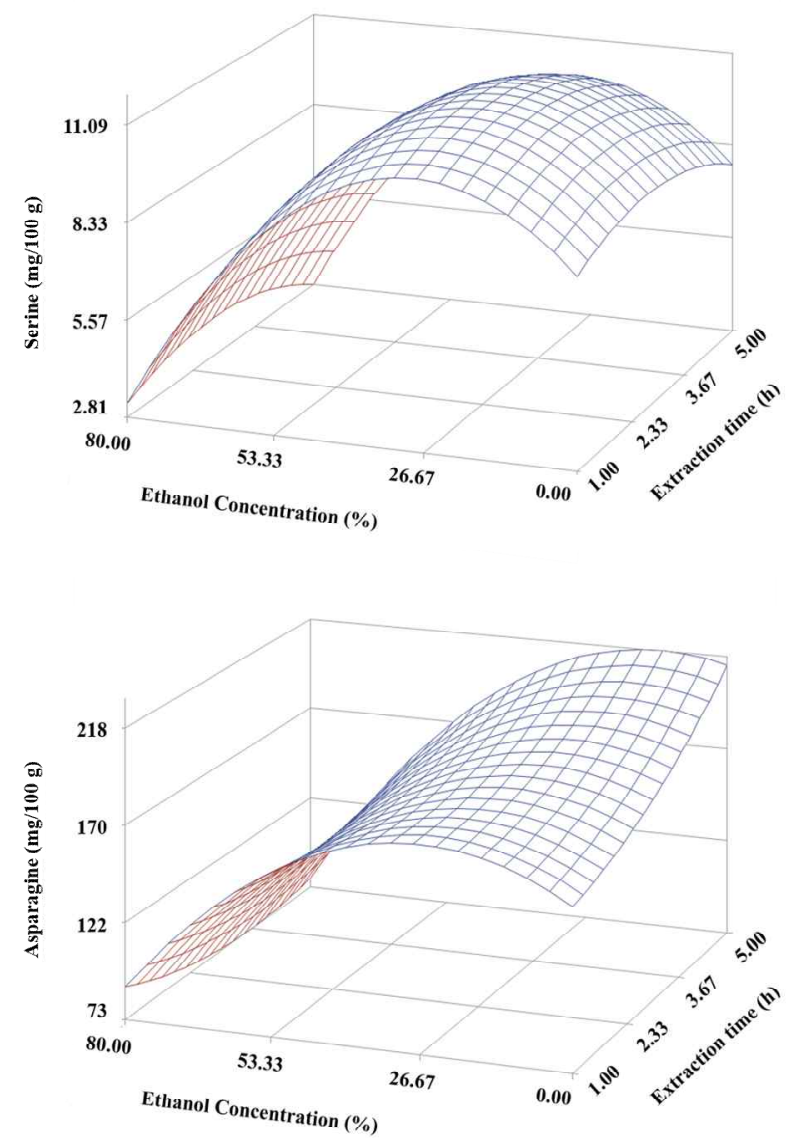

Fig. 1. Response surfaces for neutral amino acids of the dried Gugija as a function of extraction ethanol concentration and time. 
Table 5. Coefficient of determination value of polynomial equations and analysis of variance for the dried Gugija

\begin{tabular}{|c|c|c|c|c|c|}
\hline \multirow{2}{*}{ Responses } & \multirow{2}{*}{$\mathrm{R}^{2}$} & \multirow{2}{*}{$\mathrm{Pr}>\mathrm{F}$} & \multirow{2}{*}{ Morphology } & \multicolumn{2}{|c|}{ F-value } \\
\hline & & & & Ethanol concentration (\%) & Extraction time (h) \\
\hline Glycine & 0.8672 & 0.0672 & Saddle point & $6.91^{* * 1)}$ & 0.65 \\
\hline Serine & 0.8390 & 0.0957 & Maximum & $6.60^{* *}$ & 0.17 \\
\hline Alanine & 0.8314 & 0.1041 & Saddle point & $5.31^{*}$ & 0.45 \\
\hline Threonine & 0.6401 & 0.3772 & Maximum & 2.03 & 0.37 \\
\hline Proline & 0.6897 & 0.2985 & Saddle point & 1.29 & 1.01 \\
\hline Valine & 0.7639 & 0.1889 & Saddle point & 3.12 & 0.99 \\
\hline Methionine & 0.9418 & 0.0140 & Saddle point & $18.15^{* \star *}$ & 1.86 \\
\hline Isoleucine & 0.7708 & 0.1795 & Saddle point & 3.65 & 0.19 \\
\hline Leucine & 0.7702 & 0.1802 & Saddle point & 3.65 & 0.47 \\
\hline Tyrosine & 0.3778 & 0.7757 & Saddle point & 0.49 & 0.16 \\
\hline Tryptophan & 0.6372 & 0.3819 & Saddle point & 1.93 & 0.14 \\
\hline Phenylalanine & 0.5276 & 0.5590 & Saddle point & 1.02 & 0.61 \\
\hline Asparagine & 0.8843 & 0.0519 & Saddle point & $8.57^{* *}$ & 0.51 \\
\hline Arginine & 0.9074 & 0.0341 & Saddle point & $11.23^{* *}$ & 0.36 \\
\hline Histidine & 0.9463 & 0.0119 & Saddle point & $20.30^{* * *}$ & 2.31 \\
\hline Carnosine & 0.9691 & 0.0040 & Saddle point & $35.52^{* * *}$ & 2.85 \\
\hline Ornithine & 0.9685 & 0.0042 & Maximum & $38.97^{* * *}$ & 2.24 \\
\hline Aspartic acid & 09052 & 0.0356 & Saddle point & $11.22^{* *}$ & 0.30 \\
\hline Glutamic acid & 0.8070 & 0.1327 & Maximum & $4.92^{*}$ & 0.00 \\
\hline Phosphoserine & 0.9305 & 0.0197 & Maximum & $14.20^{* *}$ & 2.07 \\
\hline Hydroxyproline & 0.8264 & 0.1097 & Saddle point & 2.76 & 1.88 \\
\hline ४-Amino-n-butyric acid & 0.9810 & 0.0016 & Maximum & $67.99^{* * *}$ & $10.17^{* *}$ \\
\hline Taurine & 0.2608 & 0.9011 & Saddle point & 0.28 & 0.04 \\
\hline Phosphoethanolamine & 0.8631 & 0.0711 & Saddle point & $6.94^{* *}$ & 0.15 \\
\hline Citrulline & 0.5303 & 0.5548 & Saddle point & 0.60 & 0.89 \\
\hline Hydroxylysine & 0.6182 & 0.4127 & Minimum & 1.59 & 0.79 \\
\hline Sarcocine & 0.3285 & 0.8343 & Maximum & 0.50 & 0.46 \\
\hline Ethanolamine & 0.3346 & 0.8275 & Maximum & 0.50 & 0.49 \\
\hline Total amino acids & 0.8608 & 0.0733 & Saddle point & $7.21^{* *}$ & 0.16 \\
\hline
\end{tabular}

${ }^{1) *}, \mathrm{p}<0.1 ;{ }^{* *}, \mathrm{p}<0.05 ;{ }^{* * *}, \mathrm{p}<0.01$.

의 영향이 높게 나타났으나 추출 시간의 영향은 미미하였다. 건조 구기자의 추출에 따른 염기성 유리아미노산 중에서 유의성이 인정되는 arginine, histidine, carnosine 및 ornithine 의 반응표면만을 관찰해 보면(Fig. 2), histidine은 에탄올 함량 $20 \%$ 이상에서는 급격히 감소하는 경향을 보이고 있으 며 높은 에탄올 농도에서는 추출시간이 길어질수록 더 많이 감소하는 경향을 나타내었다. 그러나 에탄올 함량 $30 \%$ 이 하에서는 추출시간이 경과할수록 점점 더 histidine이 증가 하는 경향을 나타내었다. Arginine과 carnosine 또한 histidine과 유사한 경향의 반응표면을 보이고 있어 염기성 아미노산은 추출속도가 낮아 장시간 추출해야 충분히 추출
할 수 있는 것으로 보인다. 그러나 에탄올 함량이 많은 조건 에서 장시간 추출하면 아미노산의 R기에 아미노기가 2 개 이상인 염기성 아미노산이 소실될 수도 있을 것으로 여겨진 다. 그러나 R기에 아미노기가 하나인 ornithine은 histidine, carnosine 및 ornithine과는 다소 다른 경향을 나타내어 에탄 올 함량이 많은 조건에서 안정적이나 수용액에서 단시간 추출로 쉽게 추출되어 나오는 것으로 보인다.

산성 유리아미노산과 단백질 비구성 아미노산의 변화

추출과정 중 산성 유리아미노산의 변화를 관찰해 본 결 과, 에탄올 농도 및 추출 시간의 변화에 따라 aspartic acid는 

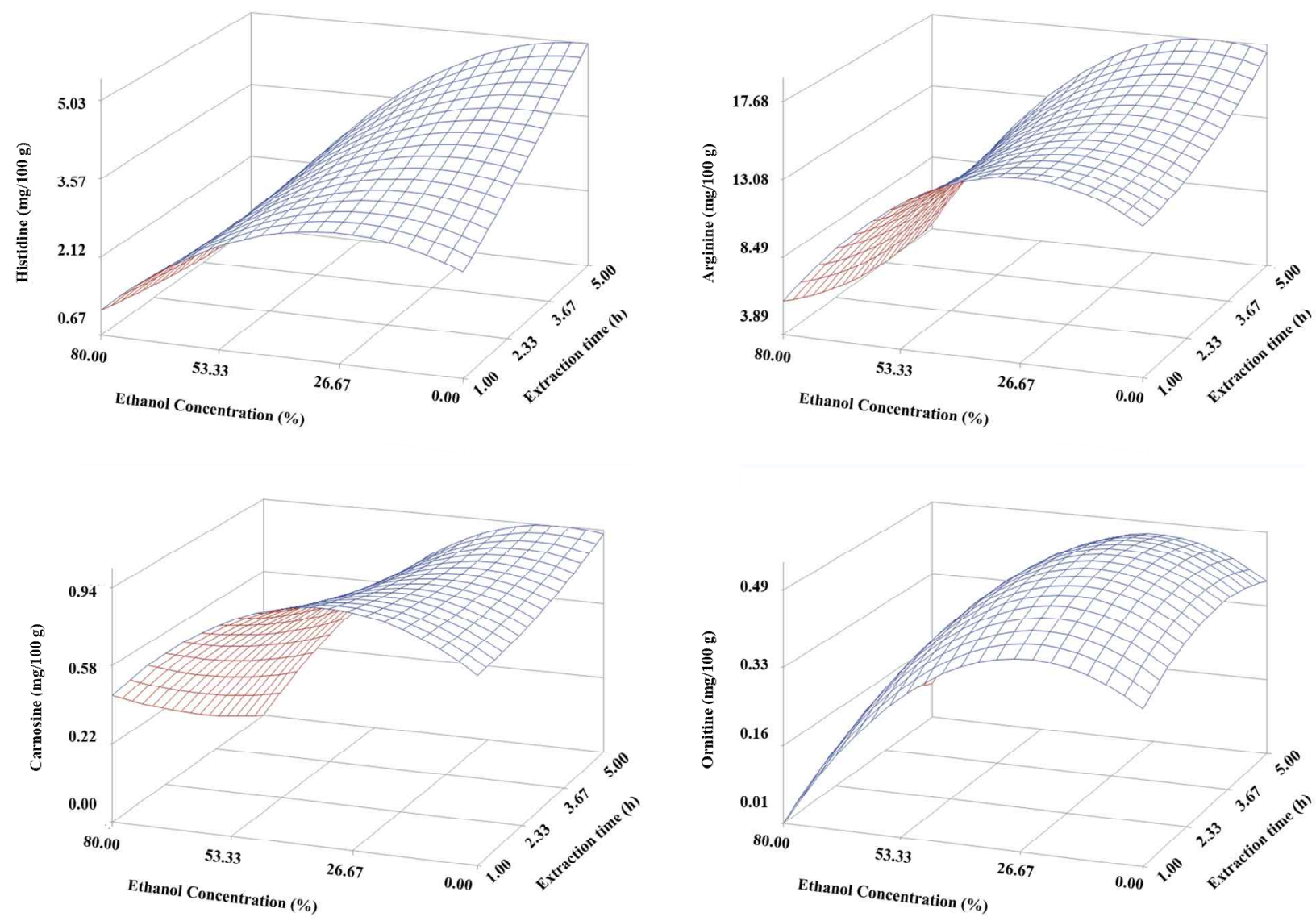

Fig. 2. Response surfaces for basic amino acids of the dried Gugija as a function of extraction ethanol concentration and time.

$5.43-28.12 \mathrm{mg} / 100 \mathrm{~g}$ 로 에탄올의 농도와 추출 시간에 따라 큰 변화가 있었으며, glutamic acid도 6.03-16.21 mg/100 g로 변화의 폭이 컸다(Table 3). Sung 등(5)은 진도산 구기자 아미노산에서 aspartic acid와 asparagine이 가장 많이 분석 되었다고 보고하여 본 연구와 유사한 것을 볼 수 있었다. 단백질을 구성하지 않는 아미노산으로는 phosphoserine, hydroxyproline, $\gamma$-amino-n-butyric acid, ornithine, taurine, phosphoethanolamine, citrulline, $\beta$-alanine, $\beta$-amino-isobutyric acid, carnosine, hydroxylysine, sarcocine, ethanolamine 등이 검출되었으며, 그 중에서 phosphoethanolamine이 59.58-174.81 $\mathrm{mg} / 100 \mathrm{~g}$ 로 가장 많은 함량이 추출되었다. 다음으로 hydroxyproline, taurine, $\gamma$-amino-n-butyric acid, phosphoserine, citrulline의 순으로 많이 추출되었다. 그 이외 $\beta$-alanine, $\beta$ -amino-isobutyric acid, hydroxylysine, sarcocine, ethanolamine 등은 미량 추출되었다(Table 3).

산성 유리아미노산 및 단백질을 구성하지 않는 유리아미 노산에 대한 회귀분석 결과(Table 4,5), 8-amino-n-butyric $\mathrm{acid}$ 의 $\mathrm{R}^{2}$ 가 0.9810 으로 유의수준 $1 \%$ 이내에서 유의성이 인정되었으며, phosphoserine 및 phosphoethanolamine의 $\mathrm{R}^{2}$ 가 각각 $0.9305,0.8631$ 로 유의수준 $5 \%, 10 \%$ 이내에서 유의
성이 인정되었다. 그러나 나머지 단백질을 구성하지 않는 유리아미노산은 유의성이 인정되지 않았다. 추출변수인 에 탄올 함량과 추출 시간이 유리아미노산에 미치는 영향을 알아보고자 회귀분석을 통해 $\mathrm{F}$ 값을 구해 본 결과(Table 5), 산성 아미노산과 phosphoserine, $\gamma$-amino-n-butyric acid, phosphoethanolamine 등 비구성 유리아미노산이 에탄올 함 량의 영향이 높게 나타났으나 추출 시간의 영향은 미미하였 다. 그러나 8-amino-n-butyric acid만이 추출 시간의 영향도 높게 나타났으며 5\%의 유의수준에서 유의성이 인정되었다.

구기자의 추출에 따른 aspartic acid, phosphoserine, phosphoethanolamine 및 $\gamma$-amino-n-butyric acid는 에탄올 함 량 $30 \%$ 이상에서는 급격히 감소하는 경향을 보이고 있으며 높은 에탄올 농도에서는 추출 시간이 길어질수록 더 많이 감소하는 경향을 나타내었다. 그리고 aspartic acid와 phosphoethanolamine은 에탄올 함량 $30 \%$ 이하에서는 추출 시간이 경과할수록 점점 더 증가하는 경향을 나타내었으 나, phosphoserine과 8-amino-n-butyric acid는 추출 시간이 2 시간 이상 경과시 감소하는 경향을 나타내었다(Fig. 3). 이러한 경향은 다른 아미노산으로 전환되거나 소실되는 것으로 여겨진다. 

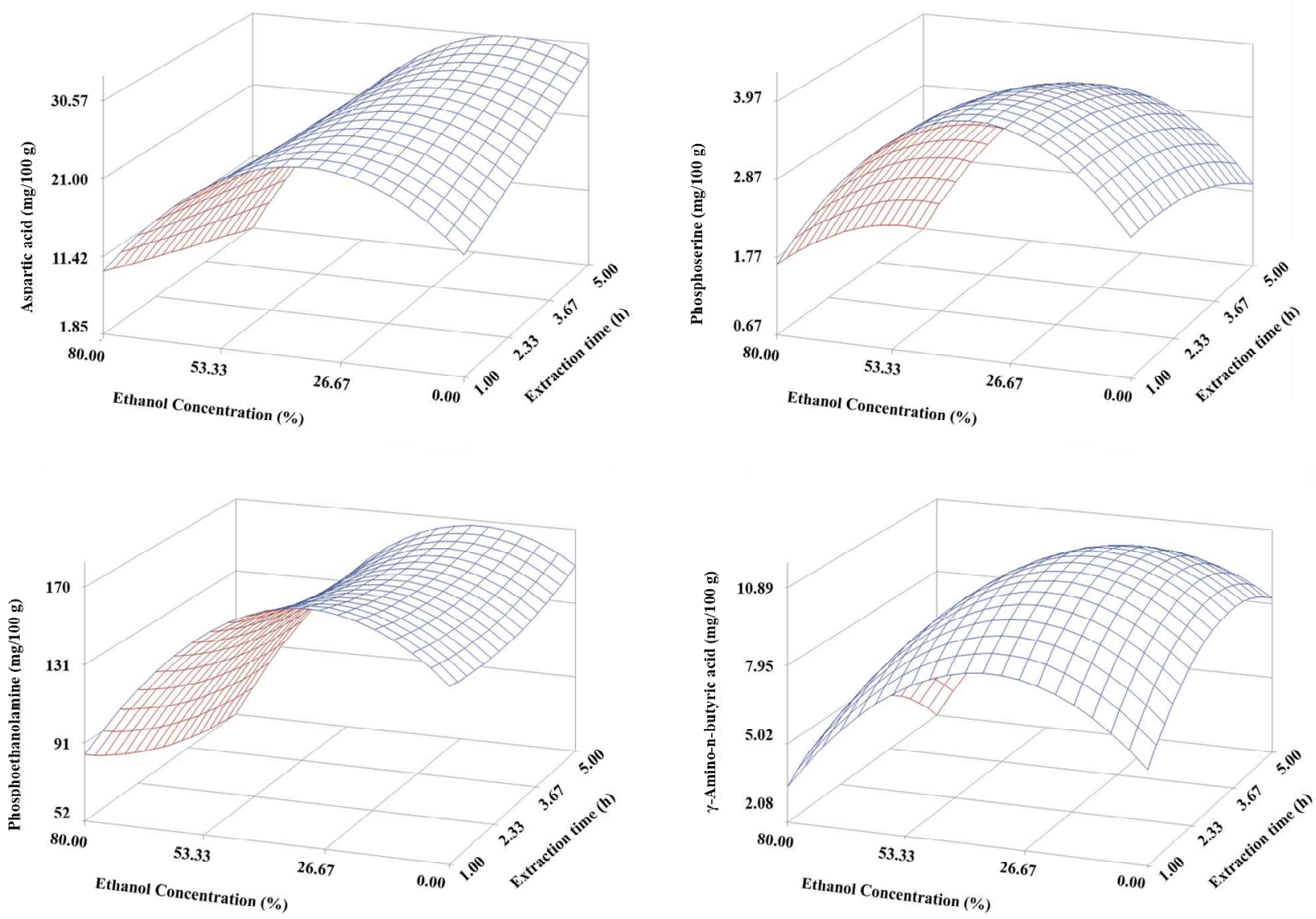

Fig. 3. Response surfaces for acidic amino acids and others of the dried Gugija as a function of extraction ethanol concentration and time.

\section{총 유리아미노산의 변화}

건조 구기자의 추출과정 중 총 유리아미노산의 변화를 관찰해 본 결과, 에탄올 농도 및 추출 시간의 변화에 따라 $282-641 \mathrm{mg} / 100 \mathrm{~g}$ 로 나타나 추출에 따라 많은 함량변화가 있었다(Table 3).

총 유리아미노산에 대한 회귀분석 결과(Table 4,5), $\mathrm{R}^{2}$ 는 0.8608 로 유의수준 $10 \%$ 이내에서 유의성이 인정되었다. 추출변수인 에탄올 함량과 추출 시간이 총 유리아미노산에 미치는 영향을 알아보고자 회귀분석을 통해 F값을 구해 본 결과(Table 5), 에탄올 함량의 영향이 높게 나타나 5\%의 유의수준에서 유의성이 인정되었다.

구기자의 추출에 따른 총 아미노산은 염기성 아미노산과 같이 에탄올 함량 $30 \%$ 이상에서는 급격히 감소하는 경향을 보이고 있으며, 높은 에탄올 농도에서는 추출 시간이 길어 질수록 더 많이 감소하는 경향을 나타내었으나 에탄올 함량 $30 \%$ 이하에서는 추출 시간이 경과할수록 점점 더 증가하는 경향을 나타내었다(Fig. 4). 총 유리아미노산의 추출 수율은 $20 \%$ 에탄올용액으로 5시간 추출할 때 가장 많이 추출되는 것으로 나타났다.

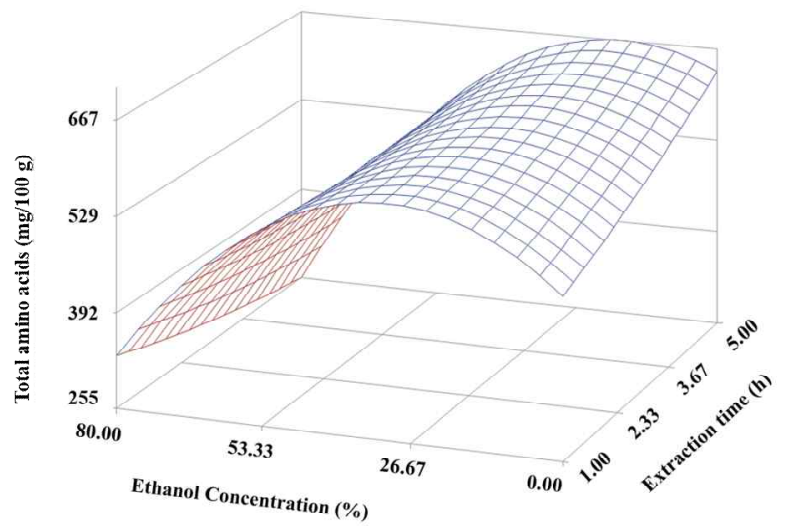

Fig. 4. Response surface for total amino acids of the dried Gugija as a function of extraction ethanol concentration and time.

\section{요 약}

본 연구는 건조 구기자의 추출에 따른 유리아미노산의 변화를 모니터링 하고자 하였으며, 추출을 위한 조건변수 
는 에탄올 농도 $\left(\mathrm{X}_{1}, 0-80 \%\right)$ 및 추출 시간 $\left(\mathrm{X}_{2}, 1-5 \mathrm{~h}\right)$ 이고, 종속변수로는 각각의 유리아미노산과 총 아미노산으로 반 응표면분석을 실시하였다. 중심합성 실험계획의 중심점에 서 유리아미노산은 asparagine 186.28, phosphoethanolamine 166.21, proline 46.51, alanine 43.35, aspartic acid 27.23, hydroxyproline 21.17 , glutamic acid 16.53 , taurine 16.24 , arginine 14.66, serine 11.65, 8-amino-n-butyric acid 10.82, leucine 10.52 , tryptophan 8.75 , ethanolamine $8.49 \mathrm{mg} / 100$ $\mathrm{g}$ 등의 순이었으며, 총 유리아미노산은 $629 \mathrm{mg} / 100 \mathrm{~g}$ 이었 다. 유리아미노산 중 $1-5 \%$ 의 유의수준에서 유의성이 인정 되는 methionine, arginine, histidine, carnosine, ornithine, aspartic acid, phosphoserine 및 $\mathrm{\gamma}$-amino-n-butyric acid에 대 한 회귀식의 $\mathrm{R}^{2}$ 는 각각 $0.9418,0.9074,0.9463,0.9691$, $0.9685,09052,0.9305,0.9810$ 으로 분석되었다. 총 유리아미 노산에 대한 회귀식의 $\mathrm{R}^{2}$ 는 0.8608 로 $10 \%$ 의 유의수준에서 유의성이 인정되었다. 건조 구기자 유리아미노산의 추출 수율은 추출조건에 따라 $282-641 \mathrm{mg} / 100 \mathrm{~g}$ 의 넓은 범위로 나타났으며, 총 유리아미노산의 추출조건은 $20 \%$ 에탄올용 액으로 5 시간 추출할 때 가장 많이 추출되었다.

\section{References}

1. Oh SL, Kim SS, Min BY, Chung DH (1990) Composition of free sugars, free amino acids, non-volatile organic acids and tannins in the extracts of $L$ chinensis $M, A$ acutiloba $K$, $S$. chinensis $B$. and $A$ sessiliflorum $S$. Korean J Food Sci Technol, 22, 76-81

2. No JG, Park WJ, Seo GS, Park JS, Cho IS, Paik SW (1996) Fatty acid and amino acid compositions of Gugiseum (Lycuim chinense Miller) depending on variety and harvest time. Korean J Plant Resour, 9, 211-217
3. Lee KA (2015) Antioxidative and anti-diabetes activity, and free amino acid and mineral contents of beverage with Gugija (Lycii fructus) extracts. Korean J Food Cookery Sci, 31, 207-213

4. Lee MY, Sheo HJ (1986) Quantitative analysis of total amino acids and free sugars in Lycii fructus. J Korean Soc Food Nutr, 15, 249-252

5. Sung C, Oh MJ, Kim CJ (1994) On the composition of free sugars, fatty acids, free amino acids and minerals in Lycuim fructus. Korean J Agric Sci, 21, 22-27

6. Lee KS, Kim GH, Kim HH, Lee HC, Paik SW, Lee SS (2008) Physicochemical properties of added sugar ratio on Gugija-sugar leaching by using Gugija (Lycii fructus) raw fruit. J Korean Soc Food Sci Nutr, 37, 744-751

7. Lee SH, Lee CY, Lee SG, Lee HH (2014) Analyses of amino acid concentration in the decoctions of Gagam Nanganjeon herbs. J Naturopathy, 3, 111-118

8. Lee GD (2017) Monitoring of antioxidant activities with dried Gugija (Lycium chinensis Mill) extraction. Korean J Food Preserv, 23, 859-865

9. Kim HY, Lee GD (2017) Monitoring of optimum antioxidant extraction condition of Gugija (Lycium chinensis Mill) extract. J Oil Appl Sci, 34, 451-460

10. Lee GD (2017) Monitoring of antioxidant activities and optimization of extraction conditions for steamed and dried Gugija (Lycium chinensis Mill). J Korean Soc Food Sci Nutr, 46, 1494-1501

11. Myers RH (1971) Response Surface Methodology. Allyn and Bacon Inc, Boston, MA, USA, p 127-134 